\title{
Biosynthesized Silver Nanoparticles using Schwanniomyces Vanrijiae and its Antimicrobial Activity Against Pathogens
}

\author{
Abd El-Latif Hesham*, Sabreen IH Salem, Karam A Amein, Rania Faisel and Mahmoud A \\ El-Rawy \\ Genetics Department, Faculty of Agriculture, Assiut University, Assiut 71516, Egypt
}

*Corresponding author: Abd El-Latif Hesham, Genetics Department, Faculty of Agriculture, Assiut University, Assiut 71516 ,

Egypt, Email: hesham_egypt5@aun.edu.eg; hesham_egypt5@yahoo.com

\section{ARTICLE INFO \\ Received: 幽 August 23, 2019 \\ Published: 幽 August 29, 2019 \\ Citation: Abd El-Latif Hesham, Sabreen IH Salem, Karam A Amein, Rania Faisel, Mahmoud A El-Rawy. Biosynthesized Silver Nanoparticles using Schwanniomyces Van- rijiae and its Antimicrobial Activity Against Pathogens. Biomed J Sci \& Tech Res 21(1)- 2019. BJSTR. MS.ID.003535.}

Keywords: Silver nanoparticles; Antimicrobial activity; Yeast; 26S rRNA gene sequences; Phylogenetic analysis

\begin{abstract}
Silver nanoparticles (Ag NPs) have become important scopes of research because of their applications in scientific field. The present study made insight into the using of yeast as eco-friendly and low-cost source for biosynthesis of Ag NPs. Whereas 50 yeast isolates were tested for their abilities to synthesize Ag NPs. Characterization of the Ag NPs of the most promising yeast isolate AUN-S18 was performed using UVVisible spectrophotometer, transmission electron microscopy. Ag NPs are spherical in shapes with size in the range of 9-35.5 nm. The produced Ag NPs showed antibacterial action against human and plant pathogens including, Staphylococcus aureus, Klebsiella pneumonia, Erwinia amylovora and Xauthonomas ceupestris pv.vesitcora with inhibition zone diameters ranged from $3.00-13.00 \mathrm{~mm}$.
\end{abstract}

Also, antifungal action against Rhizoctonia solani, fusarium oxysporumf.sp.lycopersici, Alternari alternate and Aspergillus niger expressed as inhibition of growth ranged from $1.40 \%-31.00 \%$ and Ag NPs against candida albicans (3.3-5.0 mm). Molecular identification of the selected yeast was detected based on 26S rRNA gene amplification and partial sequence determination. Alignment results and the comparison of $26 \mathrm{~S}$ rRNA gene sequences of the isolate to the 26S rRNA gene sequences available in GenBank database, as well as the phylogenetic analysis, confirmed the accurate position of the isolate AUN-S18 as Schwanniomyces vanrijiae.

\section{Introduction}

There is a new branch of nanotechnology present, which is bionanotechnology that merges principles of biology with physical and chemical procedures to create Nano-sized particles with specific functions [1]. The physical and chemical syntheses are extremely costly and non- ecofriendly because of the use of poisonous, combustible, and hazardous chemicals, which may present potential ecological and organic hazard and need high energy [2]. Hence, biosynthesis of nanoparticles using biological tools such as microbes or plant extracts has acquired much attention in the area of nanotechnology in last few decades [3]. Researchers and pharmaceutical organizations are searching for new antimicrobial tools due to arising of antibiotic resistant pathogenic strains causing infectious diseases [4,5]. Among nanomaterial such as copper, zinc, titanium, magnesium, silver, gold, and alginate, Ag NPs have demonstrated to be the best as they have great antibacterial agents against microbes, infections, bacteria, viruses and other eukaryotic microorganisms [6]

Ag NPs are the best utilized nanomaterial as antimicrobial agents. Also, Ag NPs appear to be great conductor, catalysts and it can be used as anti-inflammatory, antiviral agents, , anti-fungal, and anticancer [7-12], Ag NPs can utilization of water disinfection, activated carbon filters, wastewater treatment diagnosis, drug delivery, cell imaging and food quality analysis sensors [13]. The objectives of this study were (i) Characterization of the biosynthesis silver nanoparticles by using different analysis, (ii) Evaluation of the antimicrobial efficiency of the biosynthesis silver nanoparticles against various pathogenic microorganisms; (iv) sequences the $26 \mathrm{~S}$ rRNA gene to identify yeast isolate at species levels. 


\section{Materials and Methods}

\section{Pathogenic Indicators}

Human pathogens used in this study (Staphylococcus aureus, Klebsiella pneumonia and candida albicans) were obtained from Faculty of Medicine, Assiut University, Egypt. Plant pathogens (Erwinia amylovora and Xauthonomas ceupestris pvesitcora, Rhizoctonia solani, fusarium oxysporumf. sp. lycopersici, Alternari alternate and spergillus niger) Were obtained from department of plant Pathology, Assiut University, Egypt.

\section{Samples Collection and Yeasts Isolation}

Yeast strains were isolated from different locations at Assiut governorate according to [14].

\section{Sample Preparation, Silver Nanoparticles Synthesis and Purification}

Sample preparation has been done according the method described by [15] with some modifications yeast cells were allowed to grow as suspension culture in liquid media containing: 10gyeast extract; $20 \mathrm{~g}$ peptone and $20 \mathrm{~g}$ glucose the culture was incubated in an orbital shaker for 48 hours. The Yeast biomass was removed from the culture broth by centrifugation $(5000 \mathrm{rpm})$ at $10^{\circ} \mathrm{C}$ for $20 \mathrm{~min}$. Then, the biomass was washed extensively with distilled water to remove medium components then the pellet was Melted In distilled water sterile.

Synthesis of silver nanoparticles was carried out according to method described by [16] with some modifications; $20 \mathrm{ml}$ of biomass was mixed with $10 \mathrm{ml} \mathrm{AgNO}_{3}$ solution $(0.025 \mathrm{mM})$ and reaction mixture without $\mathrm{AgNO}_{3}$ was used as control. The culture was allowed to incubate in room temperature after a few minutes ago to few days; the culture solution was observed to the apparent changes in solution which ranges from silver gray to reddish brown. The Ag NPs were purified by centrifugation at 10,000 rpm for 20 min Three Times and at all times Wash Ag NPs with distilled water. The Ag NPs were purified by centrifugation at $10,000 \mathrm{rpm}$ for 10 min, and collected for further characterization, Placed Ag NPs after centrifugation and purification in the petri dishes sterile in the oven on 80c For 30 Minutes Then got the samples in dried powder.

\section{Ultraviolet-Visible (UV-VIS) Spectroscopy}

To observe the optical property of biosynthesized Ag NPs, samples were performed using UV-Vis spectrophotometer at wavelength of 300-800 $\mathrm{nm}$ [17].

\section{Transmission Electron Micrograph}

Transmission Electron Microscopy (TEM) The size and morphology of the synthesized nanoparticles were recorded by using TEM. TEM studies were prepared by drop coating silver nanoparticles onto carbon coated TEM grids. The film on the TEM grids were allowed to dry, the extra solution was removed using a blotting paper.

\section{Antibacterial and Antifungal Activity}

The Ag NPs synthesized were tested for their antimicrobial activity against different kinds of pathogenic bacteria and yeast. The tested strains included; S. aureus, K.pneumonia, c. albicans, E. amylovora and $X$. ceupestris pv.vesitcora by the agar well diffusion method according to [18], Antifungal activity of Ag NPs was detected by assay of growth inhibition of the tested fungi according to [19].

\section{DNA Extraction and 26S rRNA Gene D1/D2 Domain Amplification for Selected Yeast}

Total genomic DNA from yeast isolate AUN-S18 with the most promising ability to biosynthesis of Ag NPs was isolated, according [20]. The 26S rDNA D1/D2 domain region was amplified using the primers NL1 (5'-GCATATCAATAAGCGGAGGAAAAG-3') and NL4 (5'-GGTCCGTGTTTCAAGACGG-3') [21]. PCR was performed in a final volume of $50 \mu \mathrm{l}$ containing GoTaq green master mix (Promega, Madison, WI, USA), $1 \mu$ I DNA sample, and $1 \mu$ l of each primer (at a concentration of $0.5 \mathrm{mM}$ ) [22]. The amplification was carried out under the following conditions: an initial denaturation at $95^{\circ} \mathrm{C}$ for $5 \mathrm{~min}$, followed by 36 cycles at $94^{\circ} \mathrm{C}$ for $2 \mathrm{~min}, 52^{\circ} \mathrm{C}$ for $1 \mathrm{~min}$, $72^{\circ} \mathrm{C}$ for $2 \mathrm{~min}$; a final extension at $72^{\circ} \mathrm{C}$ for $7 \mathrm{~min}$; and then held at $4^{\circ} \mathrm{C}$. A total of $5 \mu \mathrm{l}$ of PCR products were then analyzed using $1.5 \%$ 0.5× TBE agarose gel electrophoresis. A 100-bp DNA ladder was used as a marker. Ethidium bromide was used for gel staining and photographs were taken under ultraviolet light.

\section{Purification of PCR Products and Determination of 26S rRNA Gene D1/D2 Domain Sequences}

PCR products of the correct size ( $\sim 600 \mathrm{bp}$ ) were purified with a Takara agarose gel DNA purification kit, and then sequenced in both directions using an ABI 3730 automated sequencer by Macrogen (Seoul, Korea).

\section{Phylogenetic Analyses and Comparisons of 26S rRNA Gene D1/D2 Domain Sequences}

The 26S rRNA gene D1/D2 domain sequences from yeast isolate AUN-S18 were searched in the GenBank and aligned with known 26S rRNA gene sequences using the basic local alignment search tool (BLAST) at the National Center for Biotechnology Information (http://www.ncbi.nlm.nih.gov/BLAST/). Percent identity scores were generated to identify yeast isolate. Phylogenetic tree was also constructed using MEGA version 4.0 with the neighborjoining algorithm and Jukes-Cantor distance estimation, with 1,000 bootstrap replicates, to confirm the taxonomic position of the yeast isolate AUN-S18.

\section{Nucleotide Sequence Accession Number}

The nucleotide sequences of the yeast isolate AUN-S18reported in this study have been deposited in the DDBJ (www.ddbj.nig. ac.jp/), EMBL (www.embl.de/), and GenBank nucleotide sequence databases (http://www.ncbi.nlm.nih.gov/genbank/) under accession number: MK744061. 


\section{Experiments Design and Statistical Analyses}

The experiments designed with randomized complete design. the data were subjected to Analysis of Variance (ANOVA) using Cos tat package version 6.311 (www.cohort.com). The means were compared according to Duncan's multiple range tests at $\mathrm{P} \leq 0.05$ [23].

\section{Results and Discussion}

\section{Biosynthesis of Ag Nanoparticles}

50 yeast isolates were tested for their ability to synthesize Ag NPs Changes of the solution from silver gray to reddish brown after addition of silver nitrate was used as signal of Ag NPs formation [17], the synthesis of Ag NPs by cell biomass of yeast shown in Figure 1. Development of surface Plasmon resonance in the mix of the reaction is the cause of change in the color as was previously reported [24]. plant phytochemicals or the microbial enzymes with antioxidant or reducing properties were act on the respective compounds and give the nanoparticles [25] the rich source of metabolites with negatively charged functional groups [26] amines, phenolics, proteins, terpenoids etc. play the main role in stabilization and reduction of metallic silver into Ag NPs [27]. Other research has shown that proteins exhibit paired function of $\mathrm{Ag}+$ reduction and shape-control during the biosynthesis of the $\mathrm{Ag}$ NPs [17].

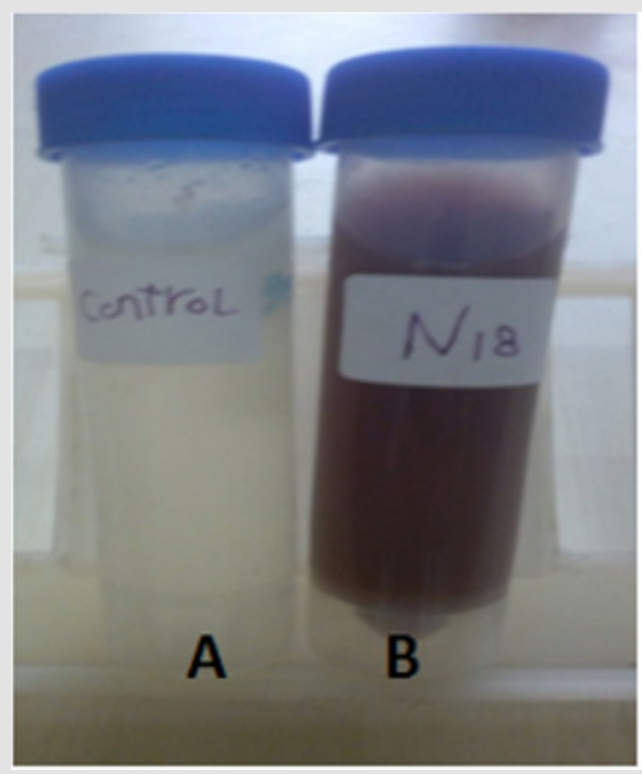

Figure1: The biosynthesis of silver nanoparticles by cell biomass of isolated yeast

A: biomass of yeast without $\mathrm{AgNO} 3$ was used as control, B: biomass of yeast $+\mathrm{AgNO}_{3}$

\section{Characterization of AgNPs UV-vis Spectroscopy}

The absorption spectra of the Ag NPs are shown in Figure 2. The sample showed the characteristic surface-plasmon of Ag NPs. Ag NPs had a narrow band with a maximum at 430nm (Figure 2). The absorption spectrum of Ag NPs showed a peak between 420 and $450 \mathrm{~nm}[28,29]$. The absorption spectrum of Ag NPs in another study showed a maximum peak at $450 \mathrm{~nm}$ [30], some studies showed that the plasmon absorbance of Ag NPs caused color change of the reaction mixture to brown and the obtained peak was at 420 $\mathrm{nm}[31]$.

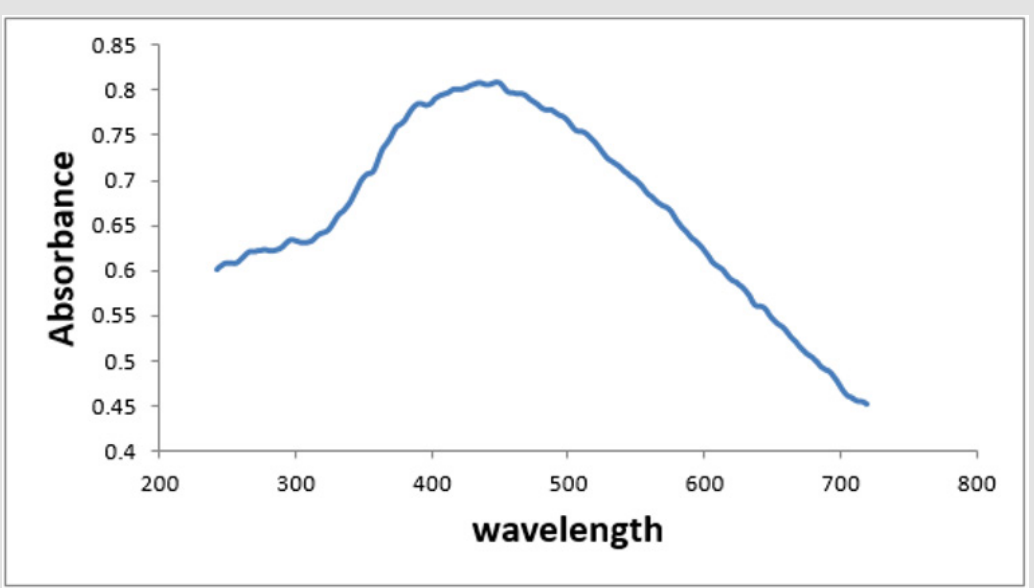

Figure 2: UV-vis spectroscopy analysis of synthesized Ag NPs solution. 


\section{Transmission Electron Microscopy (TEM)}

The TEM images of the prepared Ag NPs are presented in Figure 3 Transmission electron microscopy of synthesized silver nanoparticles revealed the formation of spherical in shapes with the size range of 9-35.5 $\mathrm{nm}$.

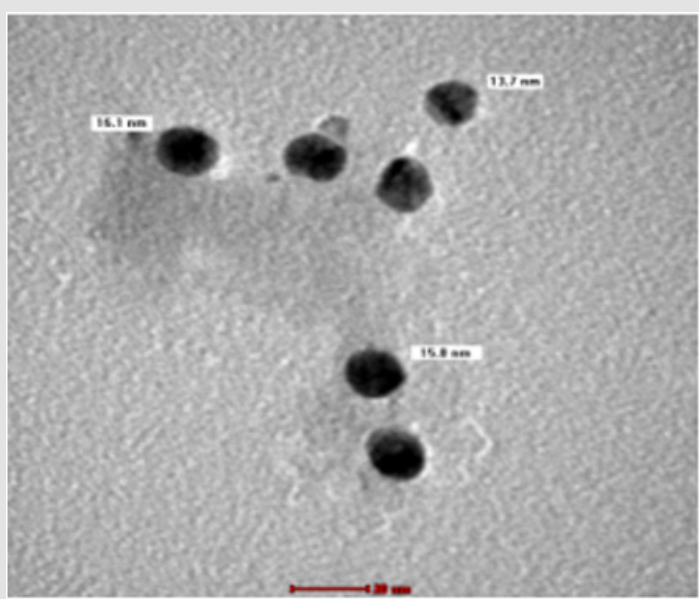

Figure 3: Transmission electron micrography of Ag NPs. Ag NPs synthesized by cell biomass of yeast analyzed by TEM.

\section{Biotechnological Applications of the Biosynthesized Ag} NPs

Table 1: Antibacterial activity of Ag NPs against pathogens.

\begin{tabular}{|c|c|c|c|}
\hline \multirow{2}{*}{$\begin{array}{c}\text { Pathogenic } \\
\text { bacteria }\end{array}$} & \multicolumn{3}{|c|}{ Inhibition rate (in mm) in various concentration } \\
\cline { 2 - 4 } & $5(\mu \mathrm{g} / \mathrm{ml}) \pm \mathrm{SD}$ & $10(\mu \mathrm{g} / \mathrm{ml}) \pm \mathrm{SD}$ & $20(\mu \mathrm{g} / \mathrm{ml}) \pm \mathrm{SD}$ \\
\hline $\begin{array}{c}\text { Erwinia } \\
\text { amylovora }\end{array}$ & $3.00 \pm 1.00 \mathrm{~B}(\mathrm{c})$ & $3.67 \pm 0.58 \mathrm{~B}(\mathrm{c})$ & $7.67 \pm 0.58 \mathrm{~A}(\mathrm{c})$ \\
\hline $\begin{array}{c}\text { Xauthonomas } \\
\text { ceupestris } \\
\text { pv.vesitcora }\end{array}$ & $6.00 \pm 1.00 \mathrm{~B}(\mathrm{~b})$ & $\begin{array}{c}7.33 \pm 1.15 \mathrm{~B} \\
(\mathrm{~b})\end{array}$ & $\begin{array}{c}11.33 \pm 1.15 \\
\mathrm{~A}(\mathrm{~b})\end{array}$ \\
\hline $\begin{array}{c}\text { Staphylococcus } \\
\text { aureus }\end{array}$ & $9.67 \pm 0.58 \mathrm{~B}(\mathrm{a})$ & $\begin{array}{c}11.00 \pm 1.00 \\
\mathrm{AB}(\mathrm{a})\end{array}$ & $\begin{array}{c}12.33 \pm 0.58 \\
\mathrm{~A}(\mathrm{ab})\end{array}$ \\
\hline $\begin{array}{c}\text { Klebsiella } \\
\text { pneumonia }\end{array}$ & $9.00 \pm 0.00 \mathrm{~B}(\mathrm{a})$ & $\begin{array}{c}10.00 \pm 1.00 \\
\mathrm{~B}(\mathrm{a})\end{array}$ & $\begin{array}{c}13.00 \pm 0.00 \\
\mathrm{~A}(\mathrm{a})\end{array}$ \\
\hline LSD (0.05) & 1.43 & 1.8 & 1.33 \\
\hline
\end{tabular}

Antibacterial Activity: It was found that, as the concentration of Ag NPS was increased, microbial growth decreases and The biosynthesized Ag NPs exhibited promising antibacterial activity against human and plant pathogens (S.aureus, K. pneumonia, E. amylovora and X.ceupestris pv.vesitcora) using agar well diffusion method. the highest antibacterial zone of inhibition (13.00 \pm 0.00 $\mathrm{mm}$ ) was recorded against $K$. pneumonia followed by $S$. aureus $(12.33 \pm 0.58 \mathrm{~mm})$ demonstrated the antibacterial effect of the Ag NPS against the test pathogens including E.amylovora and $X$. ceupestris pv.vesitcora with inhibition zone diameter (7.67 -11.33 $\mathrm{mm}$ ) (Table 1). Antibacterial activity of Ag NPs was found to be inhibitory to both human pathogenic as well as plant pathogenic bacteria, but it has more potential against human pathogenic with a small concentration of Nano and The bioavailability was high as the effect of Nano on human pathogenic bacteria lasted for 24 hours This leads to an excellent antibacterial.

Biosynthesized of Ag NPs were observed to exhibit more antimicrobial activity on $K$. pneumonia (gram-negative microorganism) than $S$. aureus (gram positive) ,These results is agree with [32], The main cause may be a difference in the cell wall of two strain; the cellular wall of gram-positive bacteria is wider than the cell wall of gram-negative bacteria [33]. The gram-negative bacteria possess an outer membrane outside the peptidoglycan layer lacking in gram-positive strains. The outer membrane of bacteria has important role of selective permeability barrier to protect it from harmful factors like drugs, detergents and toxins [34]. The bactericidal activity of Ag NPs against large number of pathogenic bacteria can be used in conjugation in impregnation techniques and polymer technology, polymer/metal Nano composites are recognized as having unique properties like antimicrobial properties, catalytic activity in diverse types of reactions, and conductivity properties, therefore they may be applied in water treatment, the textile industry, food packaging, sensors, and medical devices [35].

Antifungal Activity: The present study extended to investigate the potency of the biosynthesized Ag NPs as antifungal agents against $R$. solani, $f$. oxysporumf.sp.iycopersici, A. alternate and A. niger (Table 2). Results shown that, the highest antifungal agents of inhibition (31\%) was recorded against $f$. oxysporumf.sp.iycopersici followed by $R$. solani $14.40 \%$ Ag NPs caused $21.6 \%$ was against Ag NPs caused $15.50 \% \%$ was against A. alternate, the lowest antifungal agents were recorded agains $A$. niger (Table 2). Testing of biosynthesized nanoparticles as fungicides was previously reported in different studies [30,36].

Table 2: Antifungal activity of Ag NPs against pathogens.

\begin{tabular}{|c|c|c|c|}
\hline $\begin{array}{l}\text { Pathogenic } \\
\text { fungi }\end{array}$ & \multirow{5}{*}{ Conc. $(50 \mu \mathrm{g})$} & Mean \pm SD & $\begin{array}{c}\text { Inhibition } \\
\text { percentages }\end{array}$ \\
\hline Fusarium solani & & $26.00 \pm 1.00 \mathrm{~A}$ & $31.00 \%$ \\
\hline $\begin{array}{l}\text { Rhizoctonia } \\
\text { solani }\end{array}$ & & $22.00 \pm 1.00 \mathrm{~B}$ & $14.40 \%$ \\
\hline Alternari sp & & $19.67 \pm 0.58 \mathrm{C}$ & $15.50 \%$ \\
\hline spergillus niger & & $21.00 \pm 1.73 \mathrm{BC}$ & $1.40 \%$ \\
\hline \multicolumn{2}{|c|}{$\operatorname{LSD}(0.05)$} & 2.17 & - \\
\hline
\end{tabular}

\section{Ag NPs against Candida Albicans}

We tested three concentrations $(5 \mu \mathrm{g} / \mathrm{ml}, 10 \mu \mathrm{g} / \mathrm{ml}$ and $20 \mu \mathrm{g} /$ $\mathrm{ml}$ ) of Ag NPS against C. albicans but did not give any result and then we used higher concentrations $(30 \mu \mathrm{g} / \mathrm{ml}, 40 \mu \mathrm{g} / \mathrm{ml}$ and $50 \mu \mathrm{g} / \mathrm{ml}$ ) It was found that, as the concentration of Ag NPS was increased, microbial growth decreases, As shown in the Table 3 the highest agents of inhibition was $(5 \pm 1.00)$ follow by $(4.7 \pm 0.58)$ then (3.3 \pm 0.58 ). Testing of biosynthesized nanoparticles against $C$. albicans was previously reported in different studies $[37,38]$. 
Table 3: Biogenic synthesized Ag NPs against Candida albicans.

\begin{tabular}{|l|c|c|}
\hline Pathogenic yeast & Conc. & $\begin{array}{c}\text { Inhibition rate (in mm) in } \\
\text { various concentration } \pm \text { SD }\end{array}$ \\
\hline \multirow{4}{*}{ Candida albicans } & $30 \mu \mathrm{g} / \mathrm{ml}$ & $3.3 \pm 0.58 \mathrm{~B}$ \\
\cline { 2 - 3 } & $40 \mu \mathrm{g} / \mathrm{ml}$ & $4.7 \pm 0.58 \mathrm{AB}$ \\
\cline { 2 - 3 } & $50 \mu \mathrm{g} / \mathrm{ml}$ & $5 \pm 1.00 \mathrm{~A}$ \\
\cline { 2 - 3 } & $\mathrm{LSD}(0.05)$ & 1.48 \\
\hline
\end{tabular}

Identification using 26S rRNA gene D1/D2 Region Sequencing and Phylogenetic Analyses

Molecular techniques were used to identify and determine the phylogenetic position of yeast AUN-S18 isolate. Amplified 26S rDNA D1/D2 region from the selected isolate were $(\sim 650)$ bp long, which is the expected size (600-650) (Figure 4). Alignment of 26S rRNA gene sequences of the yeast AUN-S18 with published 26S rRNA sequences from GenBank using BLAST shows identity 99\% with Schwanniomyces vanrijiae. Phylogentic tree was constructed for AUN-S18 isolate along with other sequences of the same genus from GenBank. As shown in Figure 5 strain AUN-S18 and Schwanniomyces vanrijiae share one clade. Therefore, strain AUN-S18 was identified as Schwanniomyces vanrijiae. The 26S rRNA gene D1/D2 domain has gained recognition in yeast taxonomy as a valuable identification [39-41]. D1/D2 domain sequence databases are available for all currently recognized ascomycetous and basidiomycetous yeasts.
This makes species identification much easier and serves as a reliable and practical criterion for the identification of most known yeasts $[21,41,42]$.

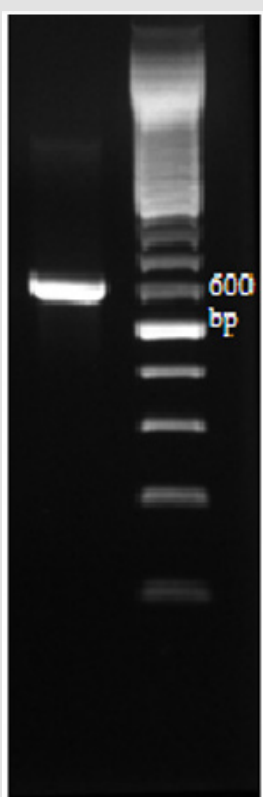

Figure 4: Amplified 26S rDNA D1/D2 domain with primer pair NL1 and NL4. Lane L represents Ladder from 1500-100 bp.; Lane 1 PCR products amplified from strain AUN-S18.

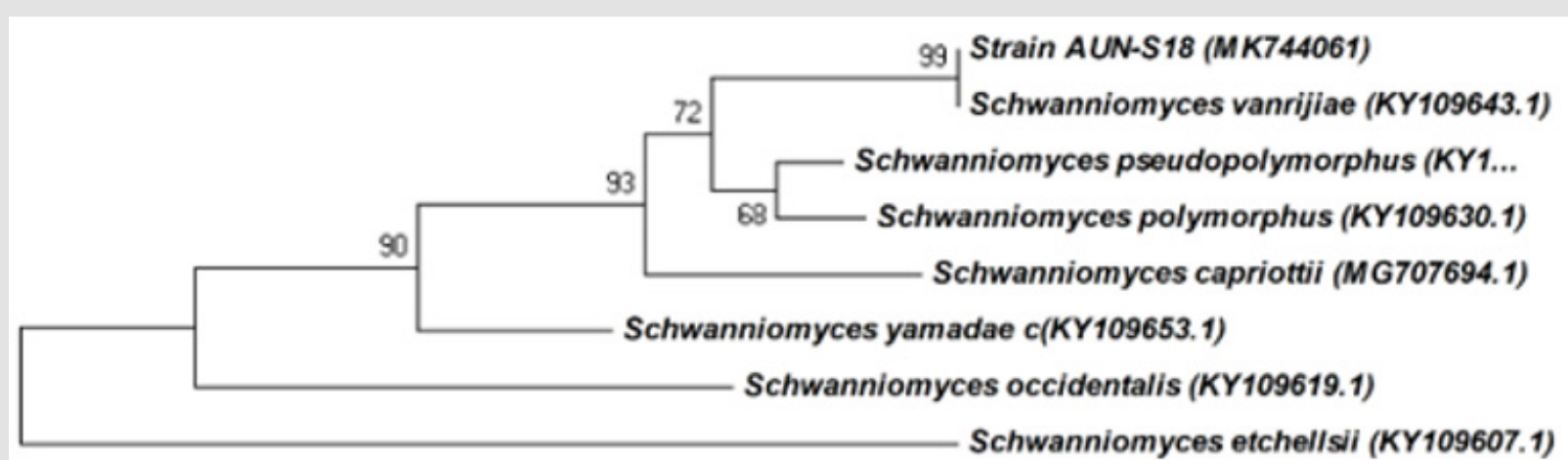

Figure 5: Phylogenetic relationship between the strain AUN-S18 and other 26S rRNA gene sequences of published Schwanniomyces strains.

\section{References}

1. Kathiresan K, Manivannan S, Nabeel M, Dhivya B (2009) Studies on silver nanoparticles synthesized by a marine fungus, Penicillium fellutanum isolated from coastal mangrove sediment. Colloids and surfaces B. Biointerfaces 71(1): 133-137.

2. Awwad AM, Salem NM, Abdeen AO (2013) Green synthesis of silver nanoparticles using carob leaf extract and its antibacterial activity. International journal of Industrial chemistry 4(1): 29.

3. Malik P, Shankar R, Malik V, Sharma N, Mukherjee TK (2014) Green chemistry based benign routes for nanoparticle synthesis. Journal of Nanoparticles.

4. Singh R, Vora J, Nadhe SB, Wadhwani SA, Shedbalkar UU, et al. (2018) Antibacterial activities of bacteriagenic silver nanoparticles against nosocomial Acinetobacter baumannii. Journal of nanoscience and nanotechnology 18(6): 3806-3815.

5. Abo-State MAM, Partila AM (2015) Antibacterial and anticancer activity of extracellular synthesized silver nanoparticles from marine
Streptomyces rochei MHM13. The Egyptian Microbial production of silver nano particles by Pseudomonas aeruginosa cell free extract. J Eco Heal Env 3: 91-98.

6. Rai M, Yadav A, Gade A (2009) Silver nanoparticles as a new generation of antimicrobials. Biotechnology advances 27(1): 76-83.

7. Saikia D, Gogoi PK, Phukan P, Bhuyan N, Borchetia S, et al. (2015) Green synthesis of silver nanoparticles using Asiatic Pennywort and Bryophyllum leaves extract and their antimicrobial activity. Adv Mater Lett 6(3): 260-264.

8. Abd Elnaby HM, Abo Elala GM, Abdel Raouf UM, Hamed MM (2016) Antibacterial and anticancer activity of extracellular synthesized silver nanoparticles from marine Streptomyces rochei MHM13. The Egyptian Journal of Aquatic Research 42(3): 301-312.

9. Ramkumar VS, Pugazhendhi A, Gopalakrishnan K, Sivagurunathan P, Saratale GD, et al. (2017) Biofabrication and characterization of silver nanoparticles using aqueous extract of seaweed Enteromorpha compressa and its biomedical properties. Biotechnology reports 14: 1-7. 
10. Kalaivani R, Maruthupandy M, Muneeswaran T, Beevi AH, Anand M, et al. (2018) Synthesis of chitosan mediated silver nanoparticles (Ag NPs) for potential antimicrobial applications. Frontiers in Laboratory Medicine 2(1): 30-35.

11. Khan SU, Anjum SI, Ansari MJ, Khan MHU, Kamal S, et al. (2018) Antimicrobial potentials of medicinal plant's extract and their derived silver nanoparticles: A focus on honeybee pathogen. Saudi Journal of Biological Sciences.

12. Shaik M, Khan M, Kuniyil M, Al Warthan A, Alkhathlan H, et al (2018) Plant-extract-assisted green synthesis of silver nanoparticles using Origanum vulgare $L$. extract and their microbicidal activities. Sustainability 10(4): 913.

13. Keat CL, Aziz A, Eid AM, Elmarzugi NA (2015) Biosynthesis of nanoparticles and silver nanoparticles. Bioresources and Bioprocessing 2(1): 47.

14. Kurtzman CP, Fell JW, Boekhout T (2011) Definition, classification and nomenclature of the yeasts. In The yeasts pp. 3-5.

15. Sheikhloo Z, Salouti M (2011) Intracellular biosynthesis of gold nanoparticles by the fungus Penicillium chrysogenum. International Journal of Nanoscience and Nanotechnology 7(2): 102-105.

16. Devi LS, Joshi S (2012)Antimicrobial and synergistic effects of silver nanoparticles synthesized using soil fungi of high altitudes of eastern Himalaya. Mycobiology 40(1): 27-34.

17. El-Sheekh MM, El Kassas HY (2014) Biosynthesis, characterization and synergistic effect of phytogenic gold nanoparticles by marine picoeukaryote Picochlorum sp. in combination with antimicrobials. Rendiconti Lincei 25(4): 513-521.

18. Bauer A, Kirby W, Sherris JC, Turck M (1966) Antibiotic susceptibility testing by a standardized single disk method. American journal of clinical pathology 45(4): 493-496.

19. Dhiman S, Singh L, Pankaj kumar, RP Bhatt (2011) In-vitro Antifungal activity of Sapium sebiferum L. against Aspergillus niger and Aflatoxigenic Aspergillus flavus. Journal of Applied Pharmaceutical Science 1(9): 108110.

20. Hesham A (2014) New safety and rapid method for extraction of genomic DNA from bacteria and yeast strains suitable for PCR amplifications. J Pure Appl. Microbiol 8(1): 383-388.

21. Kurtzman CP, Robnett CJ (1998) Identification and phylogeny of ascomycetous yeasts from analysis of nuclear large subunit (26S) ribosomal DNA partial sequences. Antonie van Leeuwenhoek 73(4): 331-371.

22. Hesham AE-L, Alrumman SA, ALQahtani ADS (2018) Degradation of toluene hydrocarbon by isolated yeast strains: molecular genetic approaches for identification and characterization. Russian journal of genetics 54(8): 933-943.

23. Duncan DB (1955) Multiple range and multiple $\mathrm{F}$ tests. Biometrics 11(1): 1-41.

24. Zarina A, Nanda A (2014) Green approach for synthesis of silver nanoparticles from marine Streptomyces-MS 26 and their antibiotic efficacy. Journal of Pharmaceutical Sciences and Research 6(10): 321.

25. Prabhu S, Poulose EK (2012) Silver nanoparticles: mechanism of antimicrobial action, synthesis, medical applications, and toxicity effects. International nano letters 2(1): 32.

26. Banerjee P, Nath D (2015) A phytochemical approach to synthesize silver nanoparticles for non-toxic biomedical application and study on their antibacterial efficacy. Nanosci Technol 2(1): 1-14.
27. Gomaa EZ (2017) Silver nanoparticles as an antimicrobial agent: A case study on Staphylococcus aureus and Escherichia coli as models for Gram-positive and Gram-negative bacteria. The Journal of general and applied microbiology 63(1): 36-43.

28. Pal S, Tak YK, Song JM (2007) Does the antibacterial activity of silver nanoparticles depend on the shape of the nanoparticle? A study of the gram-negative bacterium Escherichia coli. Appl Environ Microbiol 73(6): 1712-1720.

29. Jana NR, Sau TK, Pal T (1999)Growing small silver particle as redox catalyst. The Journal of Physical Chemistry B 103(1): 115-121.

30. Hassan SW, El-latif HHA (2018) Characterization and Applications of the Biosynthesized Silver Nanoparticles by Marine Pseudomonas sp. H64. Journal of Pure and applied Microbiology 12(3): 1289-1299.

31. Busi S, Rajkumari J, Ranjan B, Karuganti S (2014) Green rapid biogenic synthesis of bioactive silver nanoparticles (AgNPs) using Pseudomonas aeruginosa. IET nanobiotechnology 8(4): 267-274.

32. Waghmare SR, Mulla MN, Marathe SR, Sonawane KD (2015)Ecofriendly production of silver nanoparticles using Candida utilis and its mechanistic action against pathogenic microorganisms. 3 Biotech 5(1): 33-38.

33. Thiel J, Pakstis L, Buzby S, Raffi M, Ni C, Pochan DeJ, Shah SI (2007) Antibacterial properties of silver-doped titania. Small 3(5): 799-803.

34. Amro NA, Kotra LP, Wadu Mesthrige K, Bulychev A, Mobashery S, et al. (2000) High-resolution atomic force microscopy studies of the Escherichia coli outer membrane: structural basis for permeability. Langmuir 16(6): 2789-2796.

35. Tamayo L, Palza H, Bejarano J, Zapata PA (2019) Polymer composites with metal nanoparticles: Synthesis, properties, and applications Polymer Composites with Functionalized Nanoparticles pp. 249-286.

36. Ali SM, Yousef NM, Nafady NA (2015) Application of biosynthesized silver nanoparticles for the control of land snail Eobania vermiculata and some plant pathogenic fungi. Journal of Nanomaterials.

37. Ocsoy I, Temiz M, Celik C, Altinsoy B, Yilmaz V, et al. (2017) A green approach for formation of silver nanoparticles on magnetic graphene oxide and highly effective antimicrobial activity and reusability. Journal of Molecular Liquids 227: 147-152.

38. Oves M, Aslam M, Rauf MA, Qayyum S, Qari HA, et al. (2018) Antimicrobial and anticancer activities of silver nanoparticles synthesized from the root hair extract of Phoenix dactylifera. Materials Science and Engineering 89: 429-443.

39. Hong SG, Chun J, Oh HW, Bae KS (2001) Metschnikowia koreensis sp. nov., a novel yeast species isolated from flowers in Korea. International journal of systematic and evolutionary microbiology 51(Pt 5): 19271931.

40. Herzberg M, Fischer R, Titze A (2002) Conflicting results obtained by RAPD-PCR and large-subunit rDNA sequences in determining and comparing yeast strains isolated from flowers: a comparison of two methods. International Journal of Systematic and Evolutionary Microbiology 52(Pt 4): 1423-1433.

41. Hesham AEL, Khan S, Liu X, Zhang Y, Wang Z, et al. (2006) Application of PCR-DGGE to analyse the yeast population dynamics in slurry reactors during degradation of polycyclic aromatic hydrocarbons in weathered oil. Yeast 23(12): 879-887.

42. Abliz P, Fukushima K, Takizawa K, Nishimura K (2004) Identification of pathogenic dematiaceous fungi and related taxa based on large subunit ribosomal DNA D1/D2 domain sequence analysis. FEMS Immunology \& Medical Microbiology 40(1): 41-49. 
ISSN: 2574-1241

DOI: 10.26717/BJSTR.2019.21.003535

Abd El-Latif Hesham. Biomed J Sci \& Tech Res

(C) This work is licensed under Creative

Submission Link: https://biomedres.us/submit-manuscript.php

$\begin{array}{ll}\text { BIOMEDICAL } & \text { Assets of Publishing with us } \\ \text { RESEARCHES } & \text { - Global archiving of articles } \\ & \text { - Immediate, unrestricted online access } \\ & \text { - Rigorous Peer Review Process } \\ & \end{array}$

